\title{
PRPF40B Gene
}

National Cancer Institute

\section{Source}

National Cancer Institute. PRPF4OB Gene. NCI Thesaurus. Code C143090.

This gene may be involved in mRNA splicing. 